FERRET, Carole 2018 "Mobile pastoralism a century apart: continuity and change in south-eastern Kazakhstan, 1910 and 2012 ", Central Asian Survey 37 (4), p. 503-525. ISSN: 0263-4937 (Print) 1465-3354 (Online) doi: 10.1080/02634937.2018.1484698

https://www.tandfonline.com/doi/full/10.1080/02634937.2018.1484698

Author's own file, publisher's pagination is in the margin.

Carole FERRET

CNRS, Laboratoire d'anthropologie sociale, Paris

\title{
Mobile pastoralism a century apart: continuity and change in south-eastern Kazakhstan, 1910 and 2012
}

\section{Introduction}

Nomadic pastoralism had long been the main activity among the Kazakhs, who have been seen as typical steppe nomads. Yet this figure of 'the steppe nomad' is often invoked ahistorically, and is loaded with a number of stereotypes, rooted in a portrayal of nomadic pastoralism as a primitive, wandering, predatory activity, radically opposed to sedentary agriculture and subject to a strict ecological determinism (a critique that I develop further in Ferret 2012). These prejudices, which are obvious in the political rhetoric that successively blames or celebrates nomadism, but are also present more subtly in the scientific literature, should be rejected in order to study nomads in their reality and with their historicity (Ferret 2016). Contrary to implicit assumptions, studies from the Bronze Age to the twentieth century show that there probably never was a golden age when strict or pure nomadism was practised throughout the territory of present-day Kazakhstan, followed by a one-directional evolution from a nomadic to a sedentary way of life. Instead, there has been a persistent diversity of forms of nomadic pastoralism, with changing degrees of mobility. This diversity is mainly related to local environmental conditions and individual socio-economic situations.

After independence in 1991, Kazakhstan celebrated nomadism as the foundation of the nation's identity. Yet this presentation of the nomadic heritage did not break with a persistent evolutionary perspective stigmatizing nomadic pastoralism for its backwardness and relegating it to the past. It thus reveals the intrinsic ambiguity of this historical appropriation (Ferret 2016). Moreover, the celebrated figure of the nomad in national culture was largely divorced from current nomadic practices. Indeed, there is a striking contrast between the widespread celebration of nomadism and the near-total lack of ethnographic studies about present-day forms of nomadism, as though they did not exist in Kazakhstan. Apart from the role assigned to nomadism in nation-building and in the 'invention of tradition' (Hobsbawm 1983, 1-14), scholars should also address the current 
situation of mobile pastoralism in Kazakhstan through detailed case studies. In today's Kazakhstan, nomadic pastoralism is not only an aspect of heritage. It is also an existing, though minor and comparatively unacknowledged, reality.

At the end of the nineteenth century, the Kazakhs already practised various forms of nomadic pastoralism, sometimes combined with agriculture, and only a minority of them were nomads in the strict sense of year-round mobility without any fixed settlement (Ferret 2014). Nowadays the Kazakhs have a sedentary way of life, and husbandry no longer plays the primary role in the economy of the country, which has grown notably richer than neighbouring republics of Central Asia. The majority of the rural population in Kazakhstan continues to own at least a few head of livestock, and some urban dwellers even possess enormous herds. Only a tiny minority of stock breeders now regularly moves with their herds and flocks, but some of them still do, and their mobile way of life is to a certain extent similar to what was practised a century ago.

This article examines the diversity of forms of Kazakh pastoralism. It draws on a detailed investigation of a transhumance in which I took part in south-eastern Kazakhstan in June 2012 and explores the organization of life on a zhaulau (summer pastures and campsite), ${ }^{1}$ comparing these to information collected for the same area in 1910. This ethnographic account shows how mobile pastoralism still lives on in Kazakhstan, although it has undergone successive crises during the twentieth century due to Russian colonization, Soviet collectivization, and finally privatization in the 1990s.

\section{Spatial and temporal variation in Kazakh nomadic pastoralism}

The environment in which the Kazakhs live consists mainly of steppe, desert and semidesert favourable to mobile pastoralism. According to Soviet scholars, steppe lands constitute $30 \%$ of the territory of Kazakhstan, and deserts, $47 \%$, with an average annual precipitation of 200-300 $\mathrm{mm}$ on the steppe and 100-200 $\mathrm{mm}$ in the deserts (Kurylev 1998, 24-6). Nomadic or mobile pastoralism can be defined as a way of life based on the extensive husbandry of herds of herbivores (Bonte 1973), and distinguished by residential mobility. Caroline Humphrey and David Sneath have suggested replacing the word nomadism by mobile pastoralism, as the category of nomadism was 'imagined by outsiders' and 'has ceased to be useful analytically' $(1999,1)$. Some practices can nevertheless still strictly speaking be described as nomadic provided that whole families move with the livestock, not only professional herders as in transhumance. The regular movement of herds and people enables the optimal exploitation of rangelands, avoids exhaustion of natural resources, and

p.505 minimizes the need for fodder. Nomadic pastoralism works on the following principle: at any time during the year, the livestock has to be in the most favourable place; that is to say, herds must be moved from one seasonal pasture to another. In Kazakh these are the qystau in winter, kökteu in spring, zhaĭlau in summer, and küzeu in autumn (Erofeeva 2011, 10049). ${ }^{2}$ Various criteria determine the quality of pasture for a given season, including topography, vegetation, watering places, winds, snow cover and absence of insects. The most sought-after land is for winter pastures, which have to combine several conditions that are seldom all found together: good conservation of the plant cover to ensure winter grazing, and a thin layer of snow, preferably swept by winds yet protected from snowstorms (Rumiantsev 1912, I: 154). 
At the turn of the nineteenth and twentieth centuries, Kazakh groups from the three hordes (Kaz. zhüz) generally followed two main types of nomadic itinerary: most often meridian (horizontal), from south in winter to north in summer, or, more seldom, altitudinal (vertical), from plains in winter to mountain pastures in summer. In both cases, herders left the driest areas in summer and the snowiest areas in winter. These two nomadic strategies, horizontal or vertical (Johnson 1969), tend to level off climatic variations which can be very harsh in such a continental climate. They also provide watering places for livestock: either natural (streams, lakes) or artificial (wells) (Masanov 1995). The amplitude of meridian itineraries ranges from 15 to $800 \mathrm{~km}$, whereas altitudinal itineraries are usually shorter $(15-100 \mathrm{~km})$.

As a rule, nomadic itineraries were stable, with people returning to the same places every year. But the calculations that determined these itineraries were complex, and the forms of mobility diverse, ranging from strict nomadism in which stays did not exceed three months in one place, to several forms of semi-nomadism in which only part of the population moves with the livestock, or one of the seasonal stays exceeds three months, to transhumance, in which only professional shepherds move with the herds, while the rest of the population is sedentary and resides year-round in villages. ${ }^{3}$ This variety is commonly explained as reflecting differential Russian influence. However, considering that the first systematic large-scale statistical surveys on Kazakh nomads date from the end of the nineteenth century, comparison with earlier times is difficult.

To estimate available arable lands, numerous detailed inquiries were conducted during the Russian colonization of Central Asia (Materialy 1898-1909; Rumiantsev 2000 [191116]; and their analysis in Dakhshleiger 1980; Tolybekov 1971; Masanov 1995; Campbell 2011). These studies show that the most common nomadic pattern among Kazakh pastoralists at the beginning of the twentieth century was what I call 'quasi-nomadism', in which the whole human group moves with the livestock but stays from three to six months in the qystau, (winter place), where there may be permanent buildings (wooden or adobe houses, barns or corrals). The latter are not precluded by nomadism, which is primarily defined as a chronologically discontinuous occupation of space. Nor does nomadism preclude agriculture; nomadic routes simply have to pass by cultivated fields in time for ploughing, sowing, haymaking and harvesting.

The Kazakhs rear small livestock (sheep and goats) and large ones (cattle, horses, camels). These species are complementary and have a variety of uses. All of them provide various animal products (milk, meat, hair or wool, hides) and large livestock also provide energy (as pack, saddle or draught animals). The ratios of the species vary with environmental, economic and sociological conditions, and in accordance with individual wealth. The present geographical distribution of livestock is not very different from what it was a century ago, in spite of a general increase of cattle and decrease of horse and camel ratios (compare figure 1 to livestock distribution at the beginning of the twentieth century: Ferret 2014, 991). 


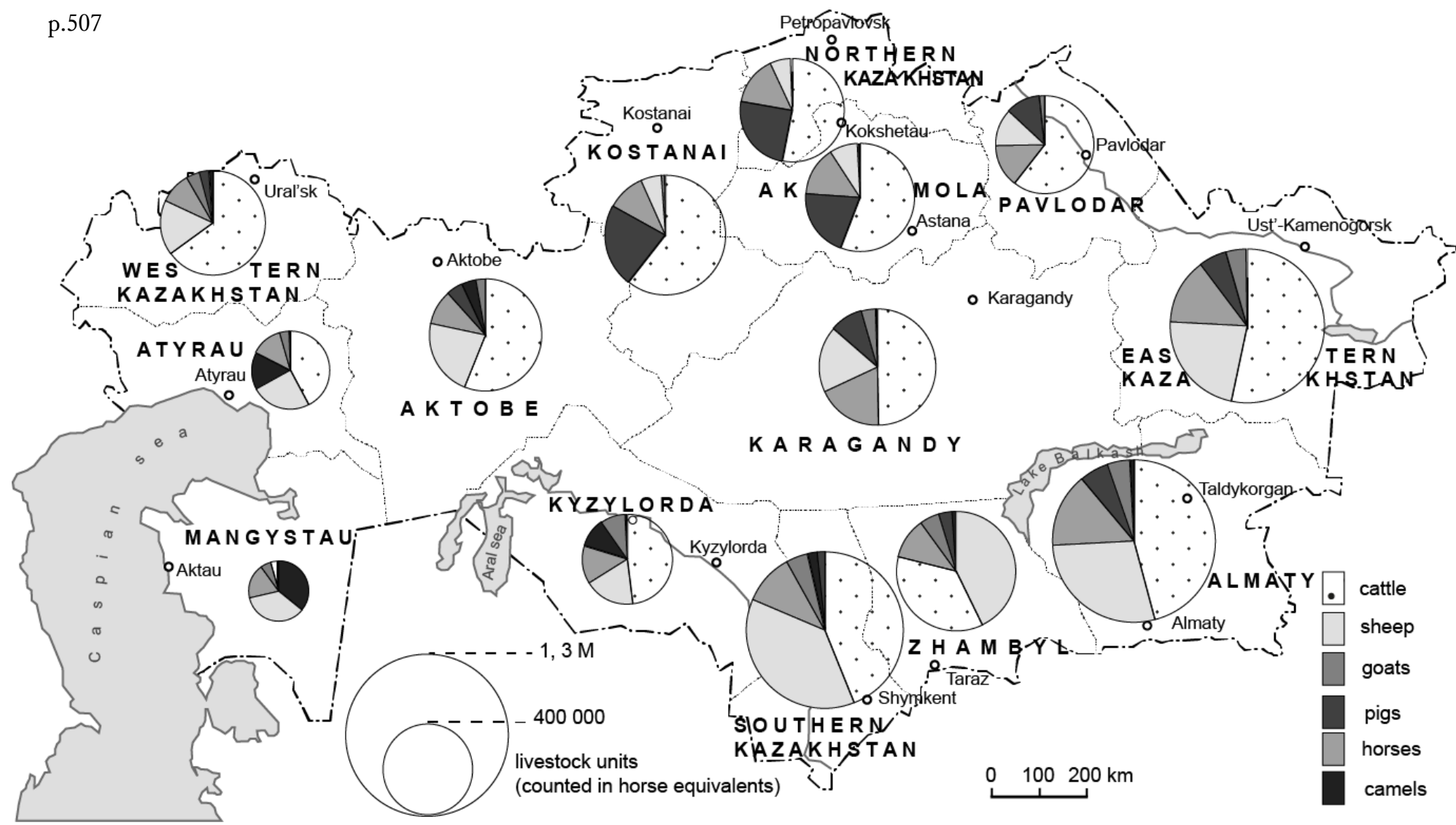

Figure 1. Livestock in the provinces (oblast') of Kazakhstan in 2006.

Map: C.Ferret. Source of data: Agency of Statistics of the Republic of Kazakhstan, National Agricultural Census of 2006.

In Almaty oblast', the richest province in livestock units followed by Southern and Eastern Kazakhstan, cattle now predominate over sheep and horses, whereas in 1910 sheep predominated, followed by horses. Small livestock nevertheless plays a major role in the south of the country.

During the twentieth century, Kazakh nomadic pastoralism endured severe crises, with serious consequences for the population. Between 1822 and 1928 sedentarization was gradual: during Russian colonization, Slavic peasants' settlement reduced the amount of available pasture, sometimes cut off nomadic routes, and led to a general territorial delimitation, especially of winter pastures (Martin 2001, 74-83; Ohayon 2014). From 1929 it tragically intensified: livestock collectivization led to the great famine of 1931-1933, and finally to the exile or death of about a third of the Kazakh population (Pianciola 2004; Ohayon 2006; Cameron 2016). The decimation of livestock due to requisitioning and illconducted collectivization suddenly deprived nomadism of its raison d'être (figure 2). Once animal husbandry was built up again in the 1940s, herds and flocks grew again and mobility was resumed among herdsmen and shepherds (Dienes 1975, 357-63; Alimaev and Behnke 2008, 163-5), but no longer concerned the rural population as a whole. In other words, Kazakh nomadic pastoralism evolved from quasi-nomadism into quasi-sedentarism or sedentarism with transhumance. ${ }^{4}$

Sovietization was subsequently accompanied by more or less successful endeavours to intensify stock breeding, as in the rest of the USSR. These included: the development of 
fodder production; the importation of new breeds that were more productive but less hardy than local breeds and less well adapted to local climatic conditions; the dominance of productivity as the primary goal (livestock reproduction rates; production of milk, meat and wool); and specialization of professions in animal husbandry (Ferret 2017). Intensification and specialization led to a reduction not only of livestock mobility but also, and above all, of people's mobility. The Kazakh population became largely sedentary. The semantic change of the Kazakh word auyl, from a 'nomadic unit' to a 'village', reveals this evolution (Ohayon 2004). The herds of the kolkhozes and sovkhozes grew; livestock numbers reached their peak in the 1980s. Herds were still moved from seasonal pastures to others, following a plan of rotational grazing on rangelands, but henceforth they were watched only by specialized professional herders who moved with them: Kaz. qoushy, shopan (Rus. chaban) 'shepherd'; Kaz. zhylqyshy (Rus. tabunshchik) 'horse herd' and Kaz. siyrshy (Rus. skotnik) 'cowherd' (figure 2).

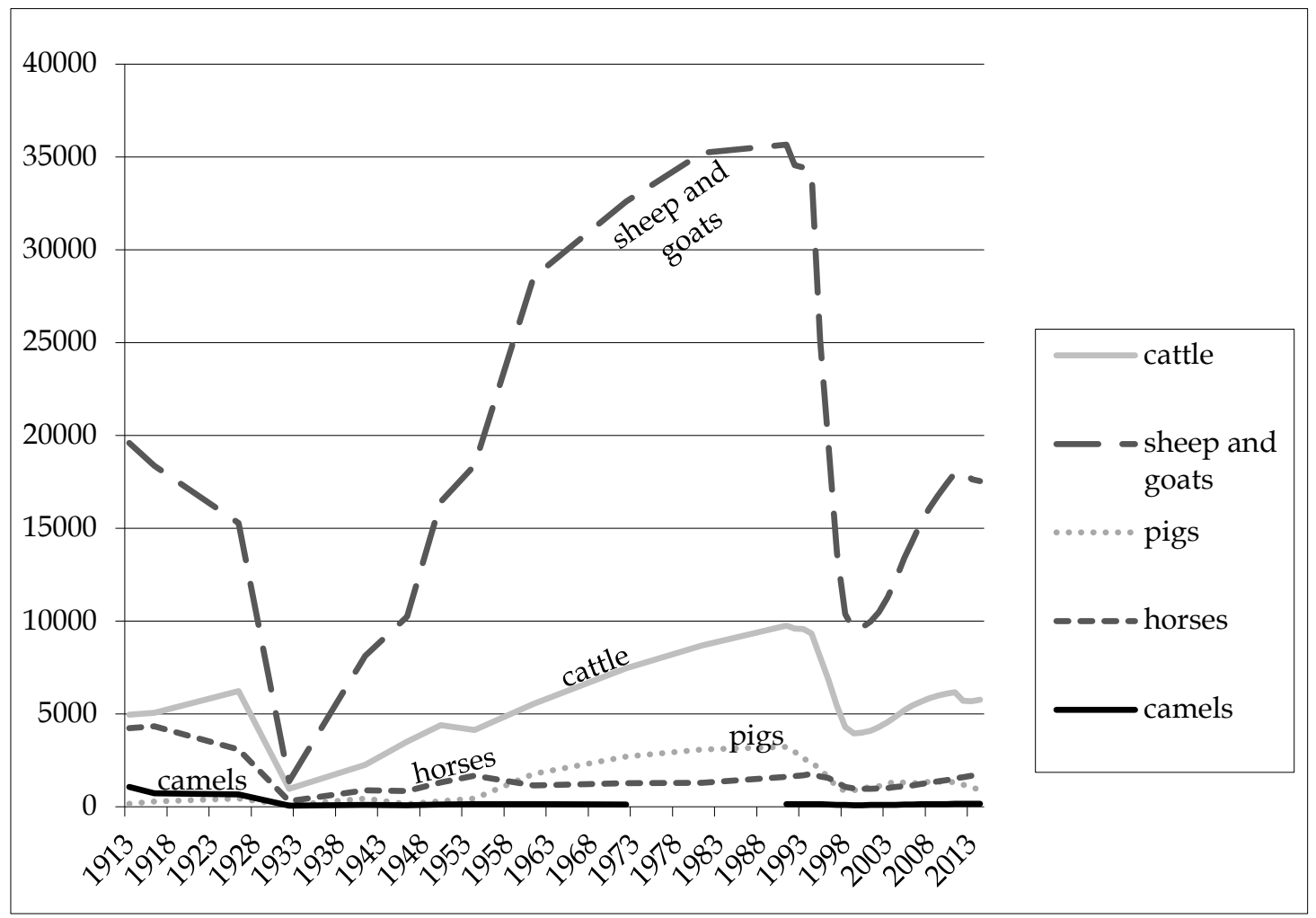

Figure 2. Livestock numbers in the present frontiers of Kazakhstan (thousands of head).

Source: Narodnoe ... 1927; Narodnoe ... 1987 and several years; Mel'nik 1967; Agency of Statistics of the Republic of Kazakhstan.

Animal husbandry collapsed during the collectivization around 1930, after which it increased up to the 1980s, then collapsed again during privatization in the 1990s.

After independence in 1991, privatization, the reverse of collectivization, also led to a severe fall in livestock numbers and a new reduction in mobility (Robinson et al. 2000; Robinson and Milner-Gulland 2003; Kerven et al. 2004, 2006). Therefore, when Kazakhs claim nowadays that they are nomads, this assertion has nothing to do with their present situation or with their actual residence pattern. Since 2000 livestock numbers have, however, been progressively built up, and some herders have again taken up a mobile form 
of pastoralism. Present forms of meridian pastoralism have been studied by a multidisciplinary team in the Moiynkum District in south-central Kazakhstan (Kerven et al. 2016a, 2016b). These case studies showed the pastoral exploitation of different eco-zones from south to north, offering seasonally-shifting advantages and disadvantages for the livestock. This exploitation depends not only on biophysical factors, but also on institutional and economic ones. The new pastoral elites, owning large flocks, have recently extended grazing sites further away from villages, colonizing former Soviet state-owned remote pastures. Yet no such survey has been conducted on vertical pastoralism in Kazakhstan. Though much more modest in its scale, this present case study in Răymbek District, mainly based on my field studies conducted in 2012 and 2013, aims to fill this gap.

\section{Vertical pastoral nomadism in Semirech'e, from the Dzharkent}

\section{District in 1910 to the Răymbek District in 2012-13}

Kazakhstan is mainly composed of low endoreic plains, but the eastern and south-eastern fringes differ from the rest of the country due to the presence of high-altitude mountains which favour vertical nomadism.

The province of Almaty is characterized by vertical climatic differentiation. The mean annual temperature drops by $0.4-0.5^{\circ} \mathrm{C}$ for every $100 \mathrm{~m}$ in altitude, and rainfall increases from $150-220 \mathrm{~mm} / \mathrm{y}$ on the plains to $880 \mathrm{~mm} / \mathrm{y}$ on the high mountain slopes. Stipa (feather grass) and Artemisia (sagebrush) are nevertheless found right up to high altitudes, as eternal snow is found $1000 \mathrm{~m}$ higher in the Tian-Shan than in the Alps (Akhmedova 1962, 13, 21) (Figure 3).

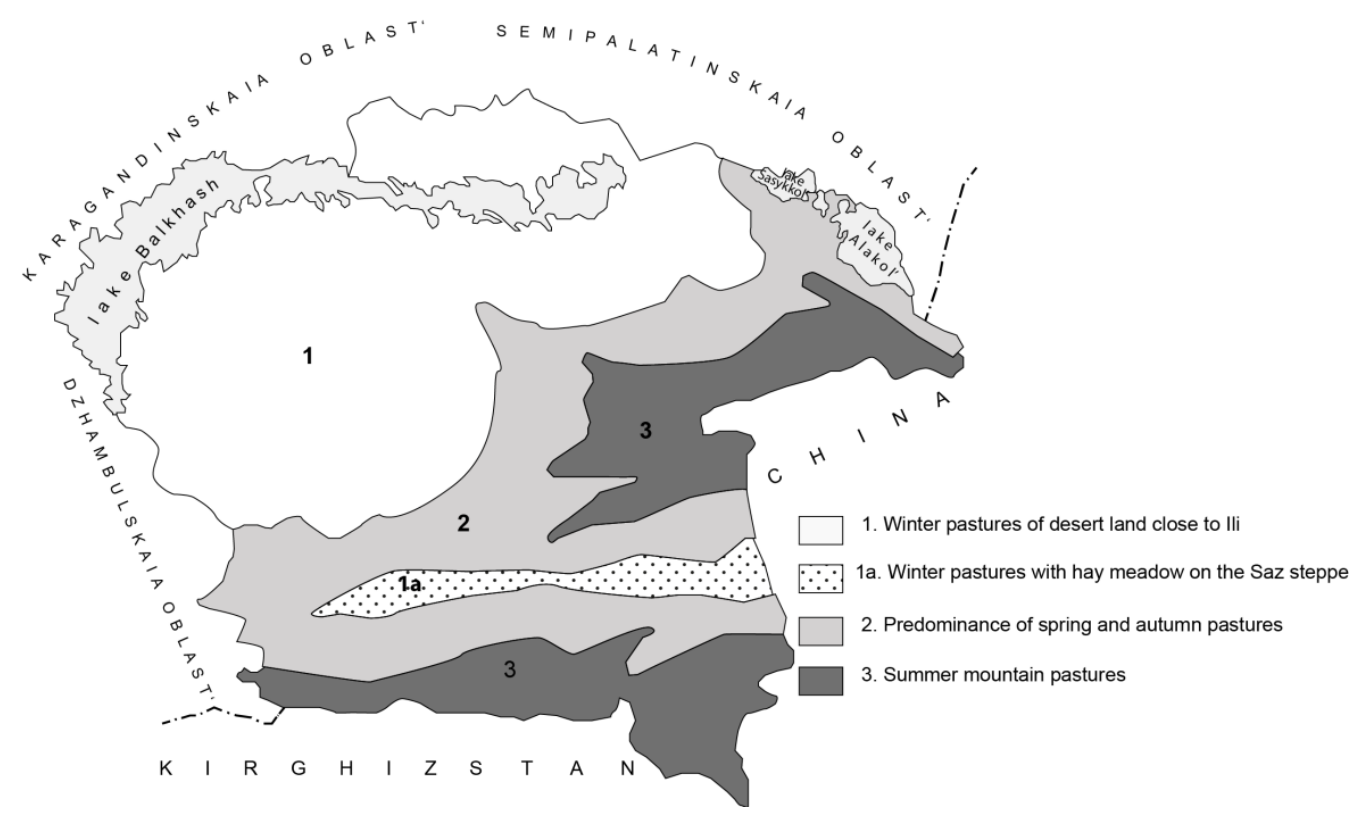

Figure 3. Seasonal distribution of pastures in Almaty Province (from Akhmedova 1962, 64). 
Rayymbek District, located at the south-eastern end of Almaty Province (and of the whole country) is exclusively rural. According to official data, in this district $99 \%$ of the population are ethnic Kazakhs (who constituted 63\% in the country's total population in 2009 but only 36\% in the 1979 census). In January 2012, 82\% of households owned livestock: on average 4.64 head of cattle, 14.24 sheep and goats, and 2.72 horses in each household, the highest rates in the province. But wealth in livestock is unequally distributed, with some owners having more than a thousand head (table 1).

\begin{tabular}{|c|c|c|c|c|c|c|c|c|c|}
\hline & population & $\begin{array}{c}\text { surface } \\
\left(\mathrm{km}^{2}\right)\end{array}$ & cattle & sheep & goats & horses & camels & $\begin{array}{c}\text { pigs } \\
\text { head of livestock } \\
\text { per inhabitant (in } \\
\text { horse equivalent) }\end{array}$ \\
\hline Kazakhstan & $16,675,400$ & $2,700,000$ & $\begin{array}{c}5,702,400 \\
(21.3 \%)\end{array}$ & $\begin{array}{c}15,197,000 \\
(56.7 \%)\end{array}$ & $\begin{array}{c}2,895,000 \\
(10.8 \%)\end{array}$ & $\begin{array}{c}1,607,40 \\
0(6 \%)\end{array}$ & $\begin{array}{c}173,200 \\
(0.6 \%)\end{array}$ & $\begin{array}{c}1,204,20 \\
0(4.5 \%)\end{array}$ & 0.62 \\
\hline $\begin{array}{c}\text { Almaty } \\
\text { Province }\end{array}$ & $1,909,260$ & 223,770 & $\begin{array}{c}828,800 \\
(19.1 \%)\end{array}$ & $3,101,500(71.4 \%)$ & $\begin{array}{c}239,000 \\
(5.5 \%)\end{array}$ & $\begin{array}{c}62,200 \\
(1.4 \%)\end{array}$ & $\begin{array}{c}111,800 \\
(2.6 \%)\end{array}$ & 0.85 \\
\hline $\begin{array}{c}\text { Ray̆mbek } \\
\text { District }\end{array}$ & 79,394 & 14,220 & $\begin{array}{c}94,700 \\
(16.5 \%)\end{array}$ & $\begin{array}{c}42,201,300(73.4 \%) \\
57,925\end{array}$ & $\begin{array}{c}5.1 \% \\
(10.1 \%)\end{array}$ & 0 & 0 \\
\hline $\begin{array}{c}\text { Zhalanash } \\
\text { rural council }\end{array}$ & 5,912 & 756 & $\begin{array}{c}5,828 \\
(13.5 \%)\end{array}$ & $\begin{array}{c}32,172 \\
(74.4 \%)\end{array}$ & $\begin{array}{c}1,803 \\
(4.2 \%)\end{array}$ & $\begin{array}{c}3,425 \\
(7.9 \%)\end{array}$ & 0 & 0 & 2.61 \\
\hline
\end{tabular}

Table 1. Population and agriculture at different territorial levels, 1 January 2012.

A century ago this area was in the Dzharkent District (uezd) in the province of 'the Seven Rivers' (Kaz. Zhetysu, Rus. Semirech'e), after the Russian conquest in the 1850s. Territorial divisions have changed since then, but some comparisons are still valuable. In 1907, horses accounted for $10 \%$ of the total livestock, cattle $9 \%$, sheep $69 \%$, goats $12 \%$ and camels 0,2\% (Obzor ... 1907). The Dzharkent District was one of the richest Kazakh districts in terms of livestock, with 8.5 horses, 0.3 camels, 6.4 cattle and 63.8 sheep and goats per household (Mel'nik 1967). With all species taken into account, livestock represented two horse equivalents per inhabitant. In this respect, the situation was similar to the present one. In 1910, Dzharkent District was the most nomadic in the province: only $3.6 \%$ of households were sedentary, although $68.5 \%$ practised agriculture (Rumiantsev 2000 [1911-16], 140) (table 2).

\begin{tabular}{|c|c|c|c|c|c|c|c|c|}
\hline & $\begin{array}{c}\text { surface area of } \\
\text { agricultural land }\end{array}$ & cattle & sheep & goats & horses & camels & $\begin{array}{c}\text { head of livestock } \\
\text { per inhabitant }\end{array}$ \\
\hline $\begin{array}{c}\text { Dzharkent } \\
\text { District }\end{array}$ & $\begin{array}{c}23,691 \mathrm{~km}^{2}, \text { of which } \\
1 \% \text { fields } \\
1 \% \text { hay meadows } \\
98 \% \text { pastures }\end{array}$ & $\begin{array}{c}92,132 \\
(8.1 \%)\end{array}$ & $\begin{array}{c}836,508 \\
(73.3 \%)\end{array}$ & $\begin{array}{c}86,039 \\
(7.5 \%)\end{array}$ & $\begin{array}{c}122,499 \\
(10.7 \%)\end{array}$ & $\begin{array}{c}3,829 \\
(0.3 \%)\end{array}$ & 3.97 \\
& & & & & \\
\hline
\end{tabular}

Table 2. Population and agriculture in Dzharkent District in 1910.

Source: Rumiantsev 2000 [1911-16]. 
Presenting the history of the Dzharkent uezd, created in 1882, Rumiantsev (1912, I: 20) shows that nomadic herdsmen and farmers succeeded and mixed with one another in the long term. After Kulzha was returned to China in 1881, the Kazakhs of the Atban and Suan p.511 clans settled on Russian territory, on the left and right banks of the Ili River respectively, whence the former chased Kirgiz of the Bogu clan towards the Przhevalsk uezd, and the latter chased other Kazakhs towards the Kopal uezd. Some Atban who had wanted to return to China in 1885 were pushed further to the west. Thus, Kazakh migrations between China and Russia, which have increased significantly since the 1990s with the arrival of the Oralman (see below), have a very long history.

Rumiantsev divided the uezd into eleven geographic areas, called 'historico-natural' zones (figure 4). The zhailau I studied was in Zone IV, which Rumiantsev (1912, I: 71)at the time also characterized as a space reserved for summer grazing. In Karkara, in the south of Kegen, a big fair was held annually from 15 June to 15 August, at which animals and animal products were sold. The rich pastures could feed large numbers of livestock in the summer. These places, with their fauna and flora, as well as the system of the three Merke rivers we crossed during the transhumance in 2012, were also described by the Russian geographer and botanist P. Semenov-Tian-Shanski1 $(1947,164-167)$ during his exploration of the Tian-Shan in 1856-1857.

\author{
(next page)
}

p.512 Figure 4. Map of the Dzharkent uezd with its 11 geographical zones defined by Rumiantsev. Map : C.Ferret. Thanks to Aset Temirgaliev and Gani Aldashev for finding the original map of Rumiantsev (1912, appendix), which I have adapted and simplified.

Those of interest to us in this study are: zone $\mathrm{V}$, corresponding to the right bank of the Chilik River, upstream; zone VIII on the left bank of the Ili, downstream of the mouth of the Charyn (the

Chilik and the Charyn are two southern tributaries of the Ili); zone VI in the valley of the

Shalkudysu-Kegen river (upstream of the Charyn); and zone IV on the Karkara high plateau. Rumiantsev's expedition aimed to gather data on environmental and living conditions in order to facilitate peasant settlers' migration to the oblast' of Semirech'e. At the same time, he identified seasonal pastures used by Kazakhs, and drew a distinction between where they were commons or only used by specific Kazakh communities (in the main part of the uezd, the latter formed long

strips of land on a north-south axis). As shown in this map, Slavic peasant settlements often encroached on Kazakh common pastures (e.g. kökteu-küzeu near Zhalanash, see close-up in figure 6). 


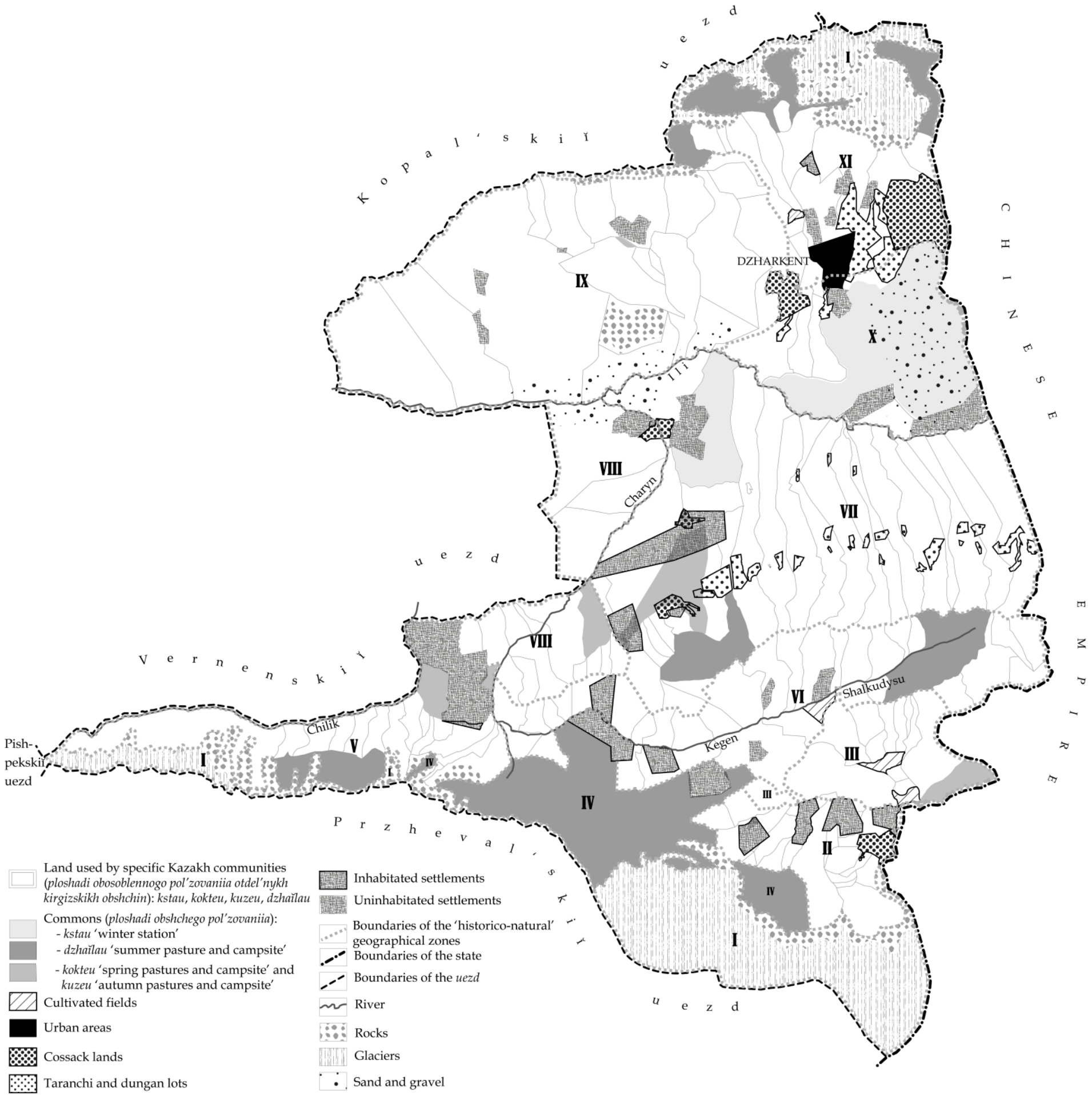




\section{In the naked plain}

The village of Zhalanash is situated at the foot of the Kunger Alatau, in a large plain watered by the Chilik and Charyn Rivers, the latter being famous for its impressive canyon. Zhalangash means 'naked, without trees' in Kazakh. In 2012, 50 households out of 786 practised mobile pastoralism and went to the mountain with their livestock in the summer. Some of them chose relatively close summer pastures, about $20-30 \mathrm{~km}$ from the village. Others, generally those who herded the biggest flocks, went to a big zhailau, to the south near Kyrgyzstan, where stockbreeders from other villages also spend the summer. About thirty yurts are pitched in this zhaŭlau, along two tributaries of a stream. This zhaŭlau was very well-patronized during Soviet times, and there was even a shop in a yurt and public baths. But it was virtually deserted between 1995 and 2000 due to a lack of livestock.

In the 1980s the kolkhoz of the neighbouring village had nearly 60,000 sheep, 4000 cattle and 8000 horses. It was disbanded in 1995 and the livestock was distributed to former kolkhoz members, theoretically in proportion to their length of service. Since the flocks had been scattered, stockbreeders were no longer required to move with their flocks; state logistic support had disappeared and funds were lacking; animal husbandry crashed, and mobility was seriously reduced. In the 2000s herds and flocks were progressively rebuilt, with a higher ratio of cattle and a lower ratio of sheep.

Once livestock numbers had increased, seasonal movement of herds became necessary because of rangeland degradation around villages due to overgrazing (Alimaev et al. 2008). Pastures near the village were no longer sufficient to feed all the animals. As a rule, large flocks are more mobile than small ones. They belong either to one or several owners, often close relatives who form a 'peasant enterprise' (Rus. krestianskoe kboziaustvo). Small owners herd their livestock together and then either send them to mountain pastures, where they are herded by a shepherd, or keep them near the village all year long in a common herd (Kaz. bada), watched in turn by each of them according to a daily rota. If we compare human and livestock mobility, we see that in this village a majority of animals and a minority of inhabitants go to a zhaŭlau.

In 1994, soon after the collapse of the USSR, I conducted an ethnographic survey of horse-rearing and breaking-in techniques in this district. At that time, animal husbandry was in decline, but Kegen sovkhoz still existed. Winter and summer pastures were situated 20-120 km from one another, and this distance was covered in 1-3 days. I was at a zhaulau then, but I did not know how this vertical nomadism would evolve from that time onwards in this district. As we were working on a collective book about nomadism in Northern and Central Asia (Stépanoff et al. 2013), I decided to take part in a transhumance (Kaz. kösh), and went to Zhalanash at the beginning of June 2012. ${ }^{5}$

In the village, it soon turned out that it would not be easy to find a shepherd who was getting ready to kösh and who would agree to take us with them. Some of the shepherds had already left; others were to go to the zhaulau later and were waiting for a wedding, for a recovery, for a funeral feast, for their son to return home, and so on. I noticed that stockbreeders were usually reluctant to set the day of transhumance in advance and to speak 
about it. On 13 June the mayor (äkim) told us that a shepherd was getting ready to leave with a large flock and many horses. Ernar, an ethnographer from Almaty, and I hurried to the shepherd's qystau $5 \mathrm{~km}$ north of the village, in steppe covered by very short and sparse vegetation.

When we arrived at the qystau, there was no one except an old woman. She told us that the cattle had already left that morning and that the sheep would only go to the zhailau the following week. In the neighbouring qystaus, situated one or two kilometres from one another, we were unable to find a way to travel to the zhailau. Then a shepherd said that he would drive a truck there the next day at 4 a.m. Their flock had already left but he would take all the equipment there by truck, and pitch their yurt on the zhaillau before the flock's arrival. In this district transhumance has been partially mechanized since the 1960s. All equipment (yurt, tools and house implements, bedding [Kaz. körpe], carpets, furniture, metal stove, fences for livestock, etc.) is transported by trucks, whereas animals move on foot. Livestock species are sometimes separated (sheep and goats always being kept in the same flock) but usually move together.

The transhumance route is more or less the same for all the stockbreeders. This nomadic pattern takes advantage of altitudinal variations of climate and vegetation. There are, however, slight fluctuations: itineraries vary in length; the number of seasonal stations also varies (from two to five, usually three); and their nomadic moves vary in time, depending on the location of their stations and from year to year, depending on weather conditions and other circumstances.

During the winter the livestock and shepherds stay in the north, on a piedmont of the Tory Arghyr (Bay Stallion) Mountain on the south-facing sunny slope (Kaz. küngě̃) where wind sweeps snow away, at an altitude of about 1500-1800 m. In spring and autumn they stay on the plain, at the lowest altitude (about 1300-1500 m). That is where the sparse vegetation, which dries out quickly in the summer, is richest in the intermediary seasons: in spring owing to the ephemeral plants, and in autumn thanks to the Artemisia (Akhmedova 1962, 37). In June they go south, to higher mountain pastures at an altitude of 2000-2500 $\mathrm{m}$ in the Kunger Alatau. These places are inaccessible in winter because of deep snow, but, as herders say, this improves the quality of the grass. Summer is rainy, and animals fatten rapidly on rich green pastures, where insects are rare. Compared to the most common meridian nomadic pattern in Kazakhstan (winter in the south, summer in the north), these seasonal moves are thus reversed along a north-south axis, for more important than latitude here is altitude and the direction of the mountain slopes (winter on the

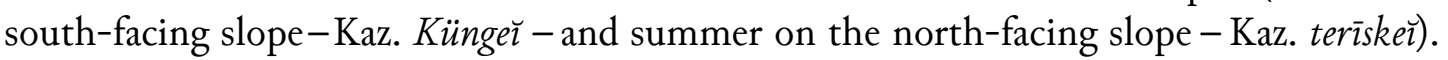



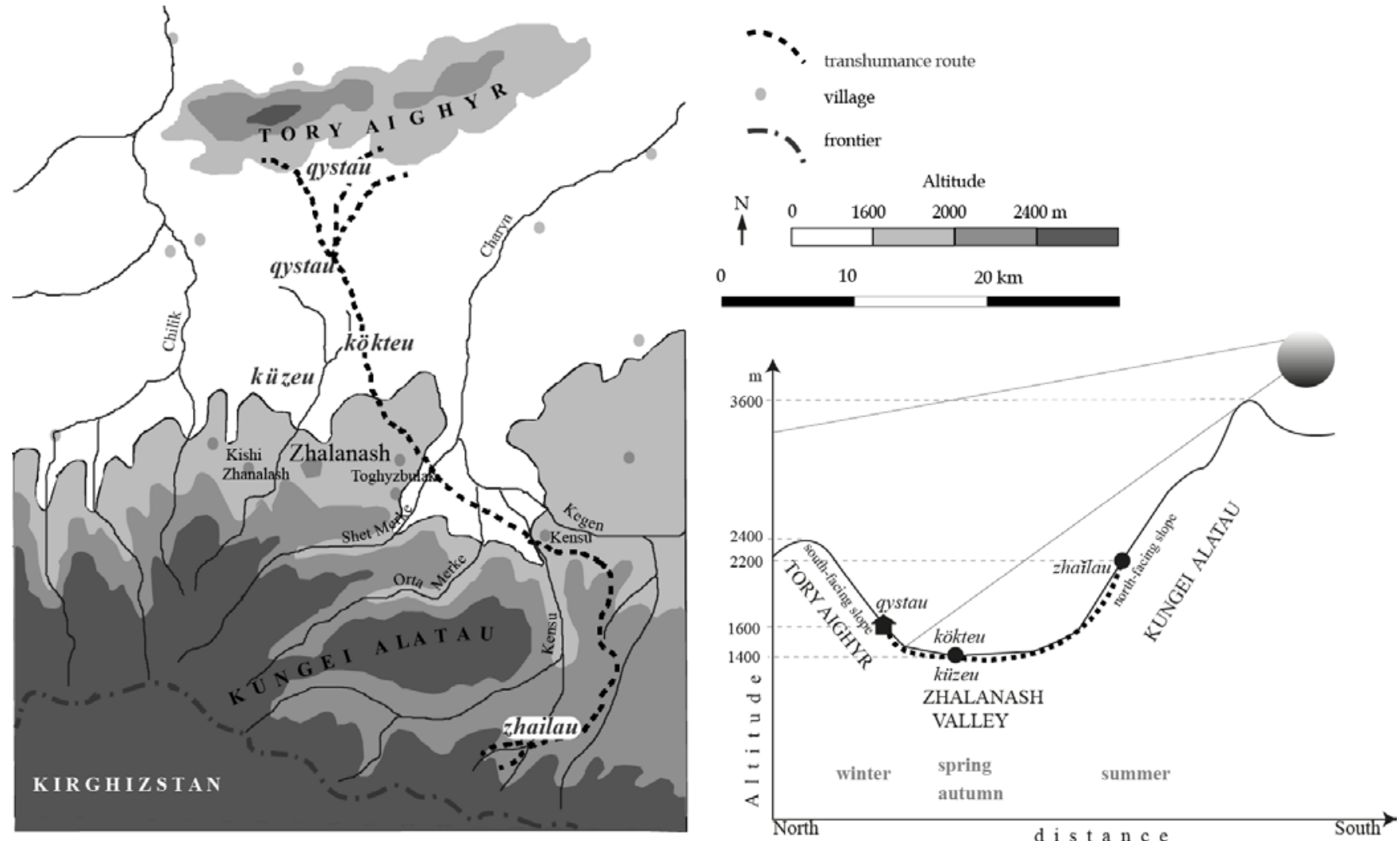

Figure 5. Transhumance route and diagram.

Map: C.Ferret

If we compare these findings with those of Rumiantsev in the early twentieth century, we note that this nomadic itinerary has hardly changed:

'[In the Zone V] the nomadic camps of the Kirghizes [Kazakhs] are basically set out as follows. On the slopes and passes of the Turăgyr [Tory Ă̆ghyr] and Kunge $\breve{1}$ Alatau Mountains we find the wintering of communities [obshchina] 78 to 92. On Mount Turargyr, where there is little snow, we find the kstau [qystau] of sheep and goats, and on the Kunger Alatau, those of the cattle. [...] As soon as spring arrives the livestock is taken towards the huge Dzhalanash valley to benefit from the fast-growing and early-flowering vegetation (cruciferous, annuals with compound inflorescence, Boraginaceae, and some Gramineae). After ploughing, some of the nomads move towards the Karkara dzbailau, while others go towards the high mountain plain where springs are found to the west of Zone V (dzhaĭlau n ${ }^{\circ} 6$ ). Later, they go back down the dzhailau via the same routes.

Thus, the magnificent mountain pastures, the semi-deserted lands of the Turăgyr, and the lowlands of Dzhalanash are all necessary and exploited at the right time' (Rumiantsev 1912, I: 81).

The principles and the implementation of the vertical scheme of pastoral nomadism have thus been constant for a century, even though no more livestock is sent to the neighbouring district. Yet, somewhat paradoxically due to the specialization of livestock farming in the Soviet days, we currently do not find this system of dual wintering with such a distinct separation between species. 
I have tried to find out more precisely which Kazakh aul among the 152 clan communities described by Rumântsev in 1910 followed the same itinerary as the one I observed in 2012. The clan community (rodovaia obshchina) $\mathrm{n}^{\circ} 74$, corresponding to administrative aul (administrativny aul) $\mathrm{n}^{\circ} \mathrm{III}^{6}$ was particularly rich in sheep and mobile. It was composed of economic auls (kboziăstvennyı aul) 1 to 64 , which wintered in the Turăgyr volost'. It consisted of 1021 individuals and 179 households, none of which were sedentary. They owned 190 yurts, two wooden houses and three adobe houses, 1203 horses, 122 camels, 800 cattle, 15,477 sheep, and 729 goats. They cultivated 3.64 ha of irrigated alfalfa and 2.48 ha of non-irrigated wheat, and in 1910 harvested 173 haycocks (kopna) used to feed their saddle horses. The rest of the livestock lived exclusively from grazing, and a part of them were sent to distant winter pastures (otgon) (1912, II: 208-17). As Rumiantsev describes the scene at that time:

'The land used exclusively by clan community $\mathrm{n}^{\circ} 74$ is situated on the rocky ground of Turăgyr, which influences their lifestyle. The most striking characteristic of this community is their flocks: they have more than 86 head of sheep and goats per household, which, in addition to the other species, makes 26 horse equivalents per household. Due to these abundant herds and flocks, and the scarcity of plant cover, they have to organize their nomadic itinerary carefully to ensure that their animals are properly fed throughout the year. Three years ago the shortage of land pushed them to attempt a migration towards the Vernyr [Almaty] uezd, but they were unsuccessful in this endeavour. Their solution was to develop ovine rearing and to remain for long periods on common land. From early spring the herds go down into the Dzhalanash valley and graze near the Dzhuvan-tiube kurgan (kokteu-kuzeu $n^{\circ} \mathrm{V}$ ). They then go further down, first downstream and then upstream of the rivers Ken'su and Tobolgaty (dzhailau $n^{\circ} \mathrm{V}$ ). From early September they move in the opposite direction towards their kstau. In total, the livestock spend almost nine months per year on the commons. In winter many nomads send their livestock to the Vernyı̆ uezd (Sugatin volost') and to the place known as Dzherkyk in the Chilik volost'. The aim is to reduce to a minimum the stay on their own territory, so that the pastures can suffice for everyone. Everywhere the pastures are used by the whole community, without any distinction according to the economic aul.

The fields cultivated by the community are situated at Dzhuvan-tûbe (kokteu-kuzeu $\left.n^{\circ} \mathrm{V}\right)$ and are worked by the few households who sow, on a first-come-first-served basis [...]. There are almost no hay meadows: the community mows only at Ashchily-togar̆ in the Kurtogar ravine in small quantities.' (Rumiantsev 1912, I: 256-7).

This description shows the pastoral strategy used by a nomadic community particularly rich in flocks: it increased its mobility in order better to exploit seasonal pastures of different tenure status. The itineraries of nomadic communities 75 and 76 , which are smaller (15 and 30 economic auls, 641 and 674 inhabitants, 1994 and 1967 head of livestock counted in horse equivalents, respectively) are similar (see figure 6; Rumiantsev 1912, I: 257-8). This example, chosen due to the proximity of the itineraries of nomadic communities 74-76 recorded by Rumiantsev's expedition in 1910 in the Dzharkent uezd, along with the transhumance that I observed in 2012 in the Răymbek District, provides us with a very enlightening comparison with the current situation. A century later, many changes have occurred, notably regarding land and livestock property, but the same pastoral route is still used by the stockbreeders with the largest flocks (compare Figures 5 and 6). 


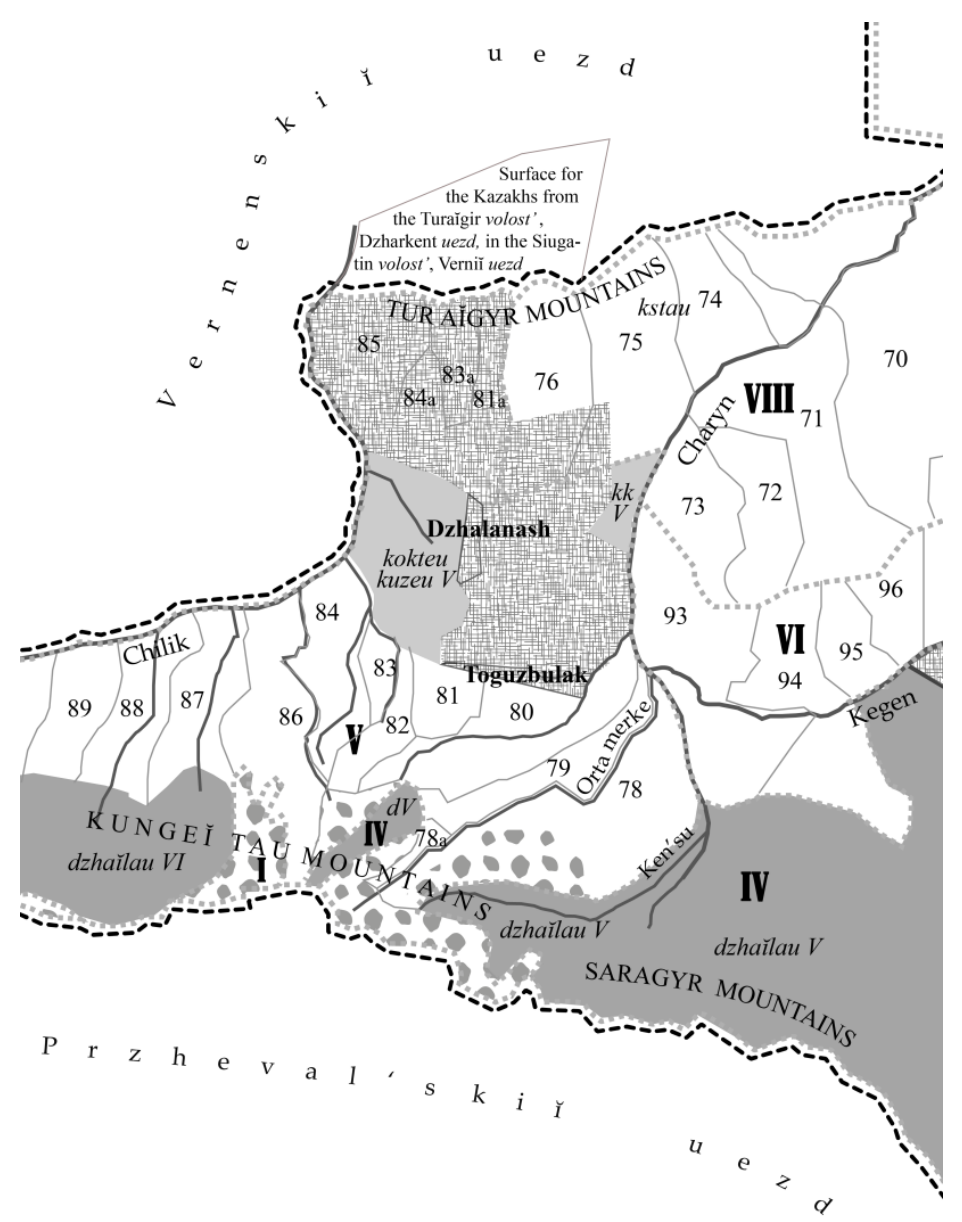

Figure 6. Seasonal pastures of communities 74-76 (close-up of Map 3).

Map: C.Ferret

Nowadays stockbreeders often have two houses: one in the village and one at their qystau. At their summer, spring and autumn stations, they live in yurts. After their departure they leave nothing at the zhălau. Pens are dismantled and reassembled every time. Nothing is left but dark traces of the sheep pen and of the place of the yurt.

Transhumance itself is led only by men, but shepherds live with their wife and their young children at all seasonal stations. After the age of seven, children go to school in the village, where they live with other relatives and then join their parents at seasonal stations during holidays. This kind of mobile pastoralism can be called quasi-sedentary: the main part of the human group lives permanently in villages, but shepherds' families live with the livestock at seasonal stations.

Approximately half of these shepherds own the livestock they herd, while the others are salaried employees. Very often one of the siblings (the youngest brother according to the Kazakh rule of ultimogeniture) herds all the livestock of the extended family, while the other siblings stay permanently in the village. Many shepherds are employed by wealthy stockbreeders. But the distinction between livestock owners and salaried employees is not always very clear, because many salaried shepherds will also own at least a few of the animals they herd. For a lively picture of transhumance I will give an ethnographic account of the transhumance in which I participated in 2012. 


\section{On the way to the zhălau}

Returning to the village from the qystau, by chance we met a nomadizing caravan. They had left their qystau, situated $35 \mathrm{~km}$ north of the village, at $4 \mathrm{a} . \mathrm{m}$. that morning. They were going to their zhaillau, walking at a very intense pace and thus covering almost $90 \mathrm{~km}$ in two days with their livestock. The chief shepherd agreed to let us go with them on foot, as there was no spare horse. So we joined the transhumance.

Everything was grey on the steppe that we crossed; not a uniform colour but a combination of tints with alternating light and shade. In the short and discontinuous ground cover, aromatic Artemisia (Kaz. myq zhusan) predominated with its small grey-green pennate leaves, with rare Stipa (Kaz. shi) tall bushes here and there near water. Large dark clouds intermittently sprayed down heavy warm rain. In the distance, rainy areas and sunny ones broke apart. Rainbows appeared so often that nobody seemed to pay attention to them.

Five horsemen led a medium-sized flock of 470 sheep and goats (Kaz. otar), among which there were 320 ewes and 47 goats, along with 21 head of cattle (cows and calves), 13 horses, a donkey and a young dog. On seasonal stations several big and small dogs usually guard each camp but they seldom help with transhumance, where they are likely to cause trouble. This pup was supposedly learning to become a sheepdog but it sometimes bit the lambs without reason. We finally lost it in a village.

The chief shepherd, who was to herd this otar on the zhaĭlau, was the most experienced. His two sons, who had completed secondary school, helped him with the transhumance. The other two horsemen also had some livestock but not in this otar. The atmosphere was quite strained between them, particularly on the second day, because the men had been drinking and the chief shepherd criticized the others for treating the sheep too roughly. One of them had beaten a ewe so violently with a stick that he had broken its spine and the animal had to be slaughtered on the way. ${ }^{7}$ Many animals had been hurt or were limping when we arrived. But the shepherd was not worried about them; he said: 'They will soon get better on the zhaulau'.

In this transhumance all species of livestock moved together. Horses often walked in front, then cattle, and the big livestock regularly left the small livestock behind. Shepherds usually rode behind the otar to drive them forward and to speed them up. From time to time they rode right or left after animals that were straying or had stopped, and then drove them back to the flock. They constantly whistled to stimulate the sheep and force them to keep up a rapid pace. Some of them cried 'qos, qos. ${ }^{8}$ As the animals became more and more tired, all possible means were used to quicken the pace: striking a stick among the flock, throwing something up in the air to frighten them, or fastening a jacket to the back of a sheep to surprise the others. Even the horn of a car overtaking the otar was welcome as it spurred the animals on.

On the first day we arrived near a river at 1 p.m. and broke for lunch to let the sheep cool down as sweaty animals must not enter cold water. Afterwards, in spite of intensive stimulation, the sheep refused to step into the river. According to the shepherds, these sheep were particularly timorous because they came from several owners' flocks. The 
hierarchy within this otar had therefore not yet been established, and there was no serke (a castrated goat whose function is to lead flocks of sheep) with undisputed authority. Since sheep do not like to walk in front, each otar has several serke which lead the whole group.

One of the shepherds forced a goat to walk across the river, but it turned back. Then the cows decided to go but they stopped in the middle of the river on a small islet. Other shepherds surrounded the otar, shouting, whistling and whipping. At last a goat made up its mind and the whole flock followed it. During the transhumance we had to cross several rivers and streams, with the same difficulties. Sometimes a few animals were carried on horses across the stream to prompt others to follow them.

That night we stopped on a farm below a village. The sheep and cattle were brought into a large barn while the horses stayed outside. The next day we started off again at 4 a.m. As we advanced, the landscape changed completely. Green replaced grey; mountains replaced plains; and light replaced shade. The livestock seemed sorry to leave such rich and green pastures dotted with flowers, so quickly. Spurred on by horsemen, ewes tried to graze and lambs to suckle, on the move. From time to time the shepherds let them graze for a while. The route was lengthened to avoid damaging high meadows before haymaking (these hay plots have been privatized but are not fenced as a rule). As soon as the shepherds were sure that we would arrive before nightfall they slowed down our pace. At last a large beautiful panorama opened before us. Below we saw the confluence that indicated the beginning of the zhălau. In fact we still had to walk for about three hours and to cross the stream five or six times to reach our place on the zhaŭlau, but all of us felt relief.

\section{On the zhălau}

p.519 On the zhaĭlau, each shepherd has a defined place to which he returns year after year, though the precise place of each yurt may vary by a few tens of metres. Yurts are located quite far from one another $(0,5-1 \mathrm{~km})$ so as to give livestock enough grazing land and to avoid the mixing of different flocks. Some yurts are situated away from the path which goes along the stream, and many times across it. If you want to visit your neighbour, a constant activity at the zhaulau, you usually need a four-wheel-drive car, a donkey or a horse. From the first yurt downstream (at an altitude of $2060 \mathrm{~m}$ ) to the last one upstream (at $2400 \mathrm{~m}$ ), you have to walk more than two hours. This difference in height explains the different dates of nomadization. The first shepherds settle downstream at the end of May or the beginning of June and stay until the end of September or the beginning of October, staying up to four months on the zhailau. But the last shepherds stay upstream less than two months (from the beginning of July to the end of August).

Land on the zhaĭlau is not privatized, but access is regulated. ${ }^{9}$ Leases are provided for a period of 49 years and stockbreeders have to pay annual taxes on land. However, parcels are not physically delimited, and livestock graze freely without limits, apart from those imposed for convenience in herding. Individual allotment of parcels may sometimes change, as I noticed when I came back to this zhaulau in 2013. According to the äkim (mayor), there are no more places available on this zhaŭlau but newcomers may still settle upstream on parcels that do not officially belong to the zhaillau area. In this case they buy an annual bilet (ticket) from the state forest agency (Rus. leskhoz), with no guarantee of renewal for the following year. For this reason stockbreeders prefer to obtain a lease on the zhaulau, on which the tax 
is not very high and which assures long-term stability. Leases also give access to the corresponding transhumance route.

Few examples of yurts among those I visited on the zhailau can be described here as characteristic cases. ${ }^{10}$ The shepherd whose transhumance I took part in had been to that zhailau for three years running. In the past he had worked in the kolkhoz and he was used to moving with flocks, but after the dissolution of the kolkhoz in 1995 he was sedentary, until 1999. He was then employed by a stockbreeder, a former sports teacher at the village school who had got rich and bought a second house in Almaty. According to common practice, the livestock owner has to provide the shepherd with a yurt. But this year the owner had kept his yurt in the village for his birthday party and given the shepherd only a tent, which was less comfortable, less warm, and not waterproof. In the mountains, the weather is rainy and nights are cold. Even in summer, stoves are lit at night. The owner had also not provided a solar battery as promised. Every month he came to the zhaillau to bring the shepherds food.

The shepherd lived on the zhaillau with his wife and with an assistant. The latter was Russian and had no home. He received no wages for his work, only board and lodgings. Shepherds' assistants are often poor single men; they have low social status and no genealogical ties with the livestock's owner. ${ }^{11}$ The shepherd's wife milked cows, separated cream with a manual cream-separator and made butter. She did the cooking and the housework, whereas men took care of the livestock. They stayed on the zhailau from 14 June to 15 September, and after the first snowfalls they went back to their autumn camp in the plain.

In August 2013 I again met this shepherd and his wife. Their yurt was set apart, quite isolated, between both tributary streams. They explained that they had changed employers because they wanted to live in a new place. Here they felt better; it was very quiet, far from other yurts. Their sons had not helped them with transhumance this year, as the elder one worked in Atyrau and the younger in Almaty.

The next yurt downstream could be distinguished by the red poles of its roof, its rich decorations and felt carpets (Kaz. syrmaq and tekemet). It came from China, like its owners, who were Oralman. Since independence, the government of Kazakhstan has followed a policy of immigration (or 'repatriation') of ethnic Kazakhs from abroad, giving Oralman public subsidies and housing support (Bonnenfant 2012). In the Rarymbek District most of the immigrants are Kazakhs from China, members of the dominant local lineage: Alban (< $\bar{U} l y$ zbüz, 'Elder Horde'). These Oralman therefore claim that they are returning to their ancestral land. This family had received a parcel on the zbălau in 2006. They were herding a large- otar of 900 head, half of which belonged to them and the other half to another livestock owner. They also had 20 horses. The head of the family had worked as a horse herder in China. There he had been accustomed to using pack animals (camels and cattle), whereas in the USSR transhumance had been mechanized since the beginning of the 1960s. In China privatization was introduced in 1983, and the lack of rangelands soon became obvious. According to this herdsman, these were the two main differences between pastoral systems, which otherwise were very similar in China and in Kazakhstan. In 2012 the aqsaqal (white beard), head of the family, and his elder son, with his wife and their three children (from 5 to 16 years old), lived in this yurt. In 2013, the son lived apart with his family, in another yurt, far downstream, where they herded another owner's livestock, while the aqsaal lived in the same yurt with other relatives. 
In a third yurt downstream lived a couple with their four children and the maternal grandmother. The husband had formerly worked in the kolkhoz as a shepherd. In 1996 he and his two brothers had set up a peasant enterprise. His wife was a doctor but no longer worked. They were herding the livestock of their extended family (300 sheep, 30 cattle and 25 horses). The other brothers lived in the village. They came to help them when necessary, particularly for transhumance, and they took charge of hay-making. The flock was common, but all decisions were made by the elder brother. In October and November they put up their yurt in the valley, $50 \mathrm{~km}$ from the zhailau, and for the rest of the year they lived at their winter station, $85 \mathrm{~km}$ from there. In 2013 they milked four mares and made qymys (fermented mare's milk), but in 2012 they could not, because all their mares had miscarriages after a zhüt (livestock losses due to bad climatic conditions). The following winter was cold but shorter, making lambing easier and livestock numbers had grown by $15 \%$ in one year.

Daily life on the zhaulau is governed by the rhythm of regular activities: herding, watching livestock, milking, taking care of animals. Most households have both small livestock, which need constant watching and are kept in a pen at night, and large livestock, which freely graze and roam. For the large livestock, the main concern is to separate milking females from young animals. Most sheep are of the arharo-merinos breed, created in Soviet times to increase wool production. Nowadays sheep are exploited for meat, because wool prices are very low, but the breed has remained the same. Only a minority of large livestock is milked for subsistence and for making butter and qūrt, a kind of dried cheese. The remoteness of the zbailau and the lack of roads make the sale of fresh milk unfeasible. Milk belongs to whoever has done the milking, whether they own the cow or not. Making qymys is a tedious task and requires frequent milking. Only one household in p.521 four produces qymys, but everyone drinks it during the frequent visits to neighbours on the zhălau.

\section{Conclusion}

This field study, which warrants further inquiry into social and territorial organization on the zhaŭlau (Ferret 2017), presents an example of mobile pastoralism in present-day Kazakhstan. It also reveals the relative continuity since 1910 in the pastoral practices of this mountainous district of south-eastern Kazakhstan. This historical continuity is remarkable in view of the political, social and economic upheavals of the twentieth century (collectivization, intensification of animal husbandry, and then privatization). The system of seasonal pastures, herds' composition, and nomadic routes have barely changed. As a former kolkhoz shepherd who is now employed by a private livestock owner commented: 'What has changed [since the end of the USSR]? Today I am free to change my employer if I don't like him.' Pastoral itineraries are sometimes more, sometimes less used by livestock and by people, depending on the current situation of animal husbandry and on the current socio-economic system, but they remain unchanged because they are most suited to the environmental conditions, optimally exploiting the vertical zoning of vegetation and the orientation of mountain slopes. Here we don't observe in the span of one century the same reduction of distances as recorded in horizontal mobile pastoralism practised in the steppes of central Kazakhstan or in other areas of mountain pastoralism in High Asia. In short, 
there are significantly fewer people moving than in the past, but those who move don't cover any less distance than their predecessors.

Sedentary forms of pastoralism now prevail in Kazakhstan: small flocks and herds graze around villages, large ones around qystau or sometimes are led in transhumance by professional shepherds. In some areas a system of seasonal pastures follows a meridian axis, in other areas, an altitudinal one, both of which can be described as quasi-sedentary patterns. In agro-pastoral family enterprises a small part of the extended family lives with the livestock all year round on different seasonal stations, whereas the other members of the family stay in the village. Within one century, the predominant form of pastoralism has changed here from quasi-nomadism to quasi-sedentarism. The seasonal rotation of pastures partly endures, as does the primacy of winter stations, but only a minor part of the population now migrates between pastures.

The research outlined above shows that contemporary Kazakh mobile pastoralism is the result of an eventful history full of conflicting trends. The examination of a transhumance to this zhălau shows, for instance, the impact of many developments: the mixture of Kazakh and Soviet methods of animal husbandry, the privatization of livestock in the 1990s, the growth of social inequalities, the new rules of land tenure, the recent repatriation of the Oralman, and the significance of kinship networks in the rural economy.

Ethnographic studies conducted a century apart in the same micro-field can also reveal large-scale and long-term changes. The comparison of two snapshots, taken in 1910 and in 2012, does not imply that the Soviet experience should be seen merely as a parenthesis. This methodological choice of a dual synchrony instead of diachrony (as would have been the study of the whole evolution from 1910s to 2010s, cf. Bosa 2011) aims instead to combine ethnography and history through the analysis of the same ethnographic field at different times. By bridging the gap between academic disciplines that have been insufficiently in dialogue with one another, such an undertaking can also illuminate the p.522 historicity of contemporary pastoral nomadism.

\footnotetext{
${ }^{1}$ A part of this study has been published in French in a book dedicated to J.-P.Digard (Ferret 2015).

${ }^{2}$ Transliteration from Cyrillic script mainly follows current Library of Congress conventions for Russian and non-Slavic (Kazakh) languages.

${ }^{3}$ The analysis of various forms of nomadic pastoralism practised at the turn of the nineteenth and twentieth centuries by several Turkic-Mongol peoples in Siberia and Central Asia (Turkmens, Kazakhs, Kyrgyz, Khakas, Buriats, Tuvans, Mongolians and Yakuts) allowed me to identify several types of nomadism, the definition of which is mainly based on residential mobility (Ferret 2014; see also Stépanoff et al. 2013, 38-42). These include:

- strict nomadism: the whole population of the group moves all year round on stable itineraries, without staying more than three months at the same place

- quasi-nomadism: all the population moves with the livestock, with a fixed settlement during one season (with or without permanent buildings)

- semi-nomadism: a minority of the population remains throughout the year at the same place, the others moving with the livestock

- semi-sedentarism: with two settlements, all the people move back and forth between a winter place and a summer place

- quasi-sedentarism: the population remains at the village all year long, except a minority of families, who move with the livestock
} 
- sedentarism: the whole population stays all year round at the same place, except the shepherds who accompany the movements of the livestock during transhumance.

${ }^{4}$ As explained in note 3, these categories reflect mobility patterns to distinguish more rigorously between nomadism and pastoralism, which are connected but distinct phenomena. If we include activities other than animal husbandry, such as crop cultivation; and livestock and land property, etc., these changes would be described differently. For instance, according to Kreutzmann's categorization of vertical mobile pastoralism in High Asia, which aims to describe agriculture in a high mountain environment and therefore can be applied only in a small part of Kazakhstan, where altitudes are lower in any case (Ehlers and Kreuzmann 2000, 13-9; Kreutzmann 2004, 54-7; Kreutzmann 2012,7-13), we would say that in this area, mobile pastoralism evolved from a mix of 'classical mountain nomadism' and 'combined mountain agriculture' at the beginning of the twentieth century, to 'transhumance' or 'detached mountain pastoralism' in the second part of the twentieth century, and finally to a mix of 'combined mountain agriculture' and 'transhumance' at the beginning of the twenty-first century.

${ }^{5}$ The word transhumance has various and contradictory definitions. Some authors use it in a broad sense (e.g. Tim Ingold), others in a strict sense (Hermann Kreutzmann). Here I understand it, like many French ethnologists, first as a system where only professional herders or shepherds move with the livestock, and second as the precise moment when they move from seasonal pastures to other ones. According to this definition, transhumance is not vertical, and it does not necessarily presume that shepherds don't own flocks.

${ }^{6}$ The census published in Materialy ... (1898-1909; Rumiantsev 1912; see also Sokolovskii 1926) uses the following units, broken down according to social, economic, genealogical and territorial criteria: khoziăstvo 'household' corresponds to a domestic unit, a family sharing the same dwelling (yurt); khoziăstvenny̆ aul 'economic aul' corresponds to a Kazakh aul (auyl), that is, a camp that groups together several households living close to one another during the cold season and then moving on together; (rodovaia) obshchina '(clan) community' is a lineage segment that shares the same territory and the same nomadic itinerary, and that groups together several economic auls; administrativnyı aul 'administrative aul' is an artificial unit, corresponding to no meaningful reality for the Kazakhs, grouping together several economic auls but which functioned de facto as the smallest administrative and territorial unit after the Russian conquest; volost' 'canton, rural commune' is a small territorial unit found throughout the Russian empire, which is smaller than the uezd 'district'. To simplify, these units can thus be grouped together and ranked: from the social and economic point of view khoziăstvo < khoziăstvennyı aul < obshchina; from the administrative and territorial point of view, adminstrativnyı̆ aul < volost' $<$ uezd.

This fact has several explanations: this man was neither the proprietor nor the herder of this flock; transhumance is a tense moment and the distance covered in one day was so great in this case that the shepherds had to hurry the animals; and treatment of animals is quite harsh in Central Asia.

${ }^{8}$ On Kazakh vocalizations used to communicate with livestock, which vary according to the species and the required movements, see Ferret $(2013,85)$, and more generally with regard to Turkic people, see the work of Dor $(2003,399)$.

${ }^{9}$ On the recent evolution of pastoral tenure in Central Asia, see Robinson et al. 2012, and also Toleubayev et al. $(2010,361)$ on the ill application and effects of the 2003 Land Code. A new Law on pastures was passed in February 2017 in Kazakhstan, but its implications are not clear yet.

${ }^{10}$ See a map of this zhălau in Ferret $(2017,181)$.

${ }^{11}$ Sokolovskii $(1926,27)$ explains that Kazakh stockbreeders usually employed shepherds from other clans.

\section{References}

Akhmedova, Kulian B. 1962. Geografiia zhivotnovodstva Alma-Atinskou oblasti. Alma-Ata: Izdatel'stvo AN SSSR.

Alimaev, Iliya, and Roy Behnke. 2008. Ideology, Land Tenure and Livestock Mobility in Kazakhstan. In Fragmentation in semi-arid and arid landscapes: Consequences for buman and natural systems, ed. K.Galvin et al., 151-178. Dordrecht: Springer. 
Alimaev, Ilya et al. 2008. The Impact of Livestock Grazing on Soils and Vegetation Around Settlements in Southeast Kazakhstan. In The Socio-Economic Causes and Consequences of Desertification in Central Asia, II, ed. R.Behnke, 81-112. Dordrecht: Springer.

Bonnenfant, Isik Kuscu. 2012. Constructing the homeland: Kazakhstan's discourse and policies surrounding its ethnic return-migration policy. Central Asian Survey 31(1): 31-44.

Bonte, Pierre. 1973. La 'formule technique' du pastoralisme nomade. Cabiers du CERM 109: 6-32.

Bosa, Bastien. 2011. Ce qui change et le déjà fait. Revue européenne des sciences sociales/European Journal of Social Sciences 2: 169-96.

Cameron, Sarah. 2016. The Kazakh Famine of 1930-33: Current Research and New Directions. East/West: Journal of Ukrainian Studies 3(2): 117-32.

Campbell, Ian W. 2011. Settlement promoted, settlement contested: the Shcherbina Expedition of 1896-1903. Central Asian Survey 30 (3/4): 423-36.

Dakhshleiger, G.F., ed. 1980. Khoziaustvo kazakhov na rubezhe XIX-XX vekov. Materialy $k$ istorikoètnograficheskomu atlasu. Alma-Ata: Nauka.

Dienes, Leslie. 1975. Pasturalism in Turkestan: Its Decline and Its Persistence. Soviet Studies 27 (3): 343-65.

Dor, Rémy. 2003. À la recherche d'un proto-langage: Analyse de quelques huchements turcs relatifs au petit bétail. Bulletin de la société linguistique de Paris 98: 385-408.

Ehlers, Eckart, and Hermann Kreutzmann. 2000. High mountain ecology and economy potential and constraints. In High mountain pastoralism in northern Pakistan, ed. E.Ehlers and H.Kreutzmann, 9-36. Stuttgart: F.Steiner.

Erofeeva, Irina V., ed. 2011. Istoriko-kul'turnyı̌ atlas kazakbskogo naroda. Almaty: Print S.

Ferret, Carole. 2012. La figure atemporelle du 'nomade des steppes'. In La Prébistoire des autres. ed. N.Schlanger and A.-C.Taylor, 167-82. Paris: La Découverte.

— 2013. Leurrer la nature : quelques exemples de manipulation des bêtes en Asie intérieure. Cabiers d'antbropologie sociale 9: 72-96.

- 2014. Discontinuités spatiales et pastoralisme nomade en Asie intérieure au tournant des XIX et $\mathrm{XX}^{\mathrm{e}}$ siècles. Annales. Histoire, Sciences sociales 69(4): 955-96.

- 2015. Une transhumance dans le sud-est du Kazakhstan. In De l'Iran au jazz, à cheval. Recueil en hommage à Jean-Pierre Digard, ed. C.Bromberger et A.Kian, 141-162. Paris: CNRS Éditions.

- 2016. The ambiguities of the Kazakhs' nomadic heritage. Nomadic Peoples 20(1): 176-199.

- 2017. Bêtes et gens. Techniques pastorales dans deux aouls kazakhs. Etudes rurales 200: 156-194 (Verte, la steppe? Agriculture et environnement en Asie centrale, ed. Marc Elie and Carole Ferret).

Hobsbawm, E. J. 1983. "Introduction: Inventing traditions ». In The Invention of tradition, edited by E. J. Hobsbawm and T. O. Ranger, 1 14. Cambridge: Cambridge University Press.

Humphrey, Caroline, and David Sneath. 1999. The end of nomadism? Society, state and the environment in Inner Asia. Durham: Duke university press.

Johnson, Douglas L. 1969. The nature of nomadism: a comparative study of pastoral migrations in Southwestern Asia and Northern Africa. Chicago: University of Chicago.

Kerven, Carol et al. 2004. Retraction and expansion of flock mobility in Central Asia: costs and consequences. African Journal of Range \& Forage Science 21(3): 159-69.

- 2006. Fragmenting Pastoral Mobility: Changing Grazing Patterns in Post-Soviet Kazakhstan. In Rangelands of Central Asia. ed. D.Bedunah et al., 99-110. Fort Collins: U.S. Department of Agriculture.

- 2016a. A pastoral frontier: From chaos to capitalism and the re-colonisation of the Kazakh rangelands. Journal of Arid Environments 127: 106-119.

- 2016b. Horseflies, wolves and wells: biophysical and socio-economic factors influencing livestock distribution in Kazakhstan's rangelands. Land Use Policy 52: 392-409. 
Kreutzmann, Hermann. 2004. Pastoral practices and their transformation in the north-western Karakoram. Nomadic Peoples 8(2): 54-88.

- 2012. Pastoral Practices in Transition: Animal Husbandry in High Asian Contexts. In Pastoral practices in High Asia: agency of 'development' effected by modernisation, resettlement and transformation, ed. H.Kreutzmann, 1-29. Dordrecht: Springer.

Kurylev, Vadim P. 1998. Skot, zemlia, obshchina u kochevykh i polukochevykh kazakhov (vtoraia polovina XIX - nachalo XX veka). Sankt-Peterburg: Muzeř antropologii i ètnografii.

Martin, Virginia. 2001. Law and custom in the steppe: the Kazakhs of the Middle Horde and Russian colonialism in the nineteenth century. London - New York: Routledge - Curzon.

Masanov, Nurbulat È. 1995. Kochevaia tsivilizatsiia kazakhov : osnovy zhiznedeiatel'nosti nomadnogo obshchestva. Almaty - Moskva: Sovinvest - Gorizont.

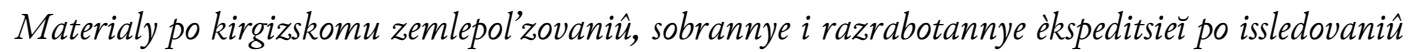
stepnykb oblasteř. 1898-1909. Voronezh - Omsk - Sankt-Peterburg: M.Z. i G.I., Departement gosudarstvennykh i zemel'nykh imushchestv.

Mel'nik, G.A., ed. 1967. Preobrazhennaia step'. Sel'skoe khoziăstvo Kazakhstana za 50 let Sovetskoř vlasti (1917-1967 gg.). Alma-Ata: Kainnar.

Narodnoe kboziaŭstvo Kazakbstana v 1925-26 god IV Statistiko-èkonomicheskiŭ ezhegodnik. 1927. KzylOrda: Izdatel'stvo Gosplana KazSSR.

Narodnoe kboziă̌stvo SSSR za 70 let.1987. Moskva : Finansy i statistika (and other years published in 1932-1991).

Obzor Semirechenskoŭ oblasti za 1906 god. 1907. Vernyŭ: Tipografiia Semirechenskogo oblastnogo pravleniia.

Ohayon, Isabelle. 2004. Du campement au village : sédentarisation et transformations de l'aoul kazakh à la période soviétique. Cabiers d'Asie centrale 13/14: 177-98.

- 2006. La sédentarisation des Kazakhs dans l'URSS de Staline: collectivisation et changement social, 1928-1945. Paris: Maisonneuve et Larose.

- 2014. Formes et usages du territoire à la période coloniale : la première sédentarisation des Kazakhs. Cabiers d'Asie centrale 23: 183-244.

Pianciola, Niccolò. 2004. Famine in the steppe. Cabiers du monde russe. 45(1-2): 137-92.

Robinson, S, Peter Finke, and Bettina Hamann. 2000. The impacts of de-collectivisation on Kazakh pastoralists: Case studies from Kazakhstan, Mongolia and the People's Republic of China. Journal of Central Asian Studies IV(2): 2-34.

Robinson, S, and E.J Milner-Gulland. 2003. Contraction in livestock mobility resulting from state farm re-organisation. In Prospects for pastoralism in Kazakstan and Turkmenistan. From state farms to private flocks, ed. C.Kerven, 128-45. London: Routledge - Curzon.

Robinson, Sarah et al. 2012. Pastoral Tenure in Central Asia: Theme and Variation in the Five Former Soviet Republics. In Rangeland Stewardship in Central Asia, ed. V.Squires, 239-74. Dordrecht: Springer.

Rumiantsev, Petr P. 1912. Materialy po obsledovaniû tuzemnogo i russkogo starozhil'cheskogo khoziaŭstva i zemlepol'zovaniia v Semirechenskor oblasti... t.III Dzharkentskĭ uezd. 2 vols. Sankt-Peterburg: Pereselencheskoe upravlenie glavnogo upravleniia zemleustroisstva i zemledeliia.

- 2000 [1911-16]. Uezdy Zhetysu. Almaty: Zhalyn baspasy.

Semenov-Tian-Shanskiĭ, Petr Petrovich. 1947. Puteshestvie v Tian'-Shan'v 1856-1857 gg. Moskva: Ogiz.

Sokolovskiī, V.G. 1926. Kazakbskĭ aul. Tashkent: Steklograf KazTsSU.

Stépanoff, Charles, Carole Ferret, Gaëlle Lacaze, and Julien Thorez, eds. 2013. Nomadismes d'Asie centrale et septentrionale. Paris, France: Armand Colin. 
Toleubayev, Kazbek, Kees Jansen, and Arnold van Huis. 2010. Knowledge and agrarian decollectivisation in Kazakhstan. The Journal of Peasant Studies 37(2): 353-77.

Tolybekov, Sergali E. 1971. Kochevoe obshchestvo kazakhov v XVII - nachale XX veka. Alma-Ata: Nauka.

Résumé:

Un siècle plus tard : le pastoralisme mobile dans le sud-est du Kazakhstan (1910, 2012)

Cet article compare deux études ethnographiques menées à un siècle d'intervalle sur le même micro-terrain, dans le sud-est du Kazakhstan : une enquête statistique datant de 1910 et le récit d'une transhumance à laquelle l'auteur a participé en 2012. Contredisant la figure atemporelle du "nomade des steppes", il présente les caractéristiques principales du pastoralisme nomade kazakh, grandement variables dans le temps et l'espace. Aujourd'hui, le pastoralisme kazakh est majoritairement sédentaire, mais un système de rotation des pâtures est toujours pratiqué dans certaines régions. Dans le district de Rajymbek (province d'Almaty), le nomadisme vertical exploite les variations altitudinales de la végétation et du climat. L'article démontre à la fois la stabilité des itinéraires de nomadisation, qui demeurent identiques en dépit des crises sévères traversées successivement au cours du $\mathrm{XX}^{\mathrm{e}}$ siècle (colonisation russe, collectivisation soviétique, privatisation postsoviétique), et une évolution générale du quasi-nomadisme à la quasi-sédentarité. Il évoque également les multiples bouleversements socio-économiques survenus depuis les années 1990. Cette comparaison à un siècle d'intervalle vise, par une approche synchronique duelle, à restaurer le dialogue entre l'histoire et l'anthropologie sociale, ainsi qu'à rendre son historicité au pastoralisme nomade.

Mots-clés : pastoralisme nomade ; ethnographie ; continuité historique ; synchronie duelle ; Kazakhstan ; postsoviétique ; transhumance.

\section{Abstract:}

Mobile pastoralism a century apart: continuity and change in south-eastern Kazakhstan, 1910 and 2012

This article challenges the ahistorical figure of the 'steppe nomad' by presenting some of the main characteristics of Kazakh nomadic pastoralism, which vary widely in time and space. It compares two ethnographic studies conducted a century apart in the same place in southeastern Kazakhstan: a statistical survey from 1910 and an account of a transhumance in which the author took part in June 2012. Sedentary pastoralism now prevails in Kazakhstan, but a system of seasonal pastures endures in some areas. In Răymbek District (Almaty Province), vertical nomadism takes advantage of the altitudinal variations of vegetation and climate. This article demonstrates both the continuity of nomadic routes despite successive crises during the twentieth century, and considers the overall change from quasi-nomadism to quasisedentarism. This comparison a century apart also fosters dialogue between history and social anthropology through a dual synchronic approach, seeking to restore historicity to our understanding of pastoral nomadism.

Keywords: nomadic pastoralism; ethnography; historical continuity; dual synchrony; Kazakhstan; postsocialism; transhumance. 
Carole Ferret is CNRS researcher, deputy director of the Laboratoire d'anthropologie sociale (CNRS - EHESS - Collège de France). Her research project, 'Treatment of nature and treatment of others: An anthropology of action among two pastoral peoples of Central Asia and Eastern Siberia', explores to what extent groups can be distinguished by a propensity for certain ways of doing.

Email : carole.ferret@college-de-france.fr

\section{Contents}

Introduction 1

Spatial and temporal variation in Kazakh nomadic pastoralism...................................................... 2

Vertical pastoral nomadism in Semirech'e, from the Dzharkent District in 1910 to the Răymbek

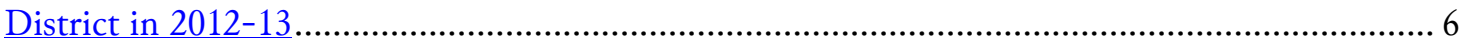

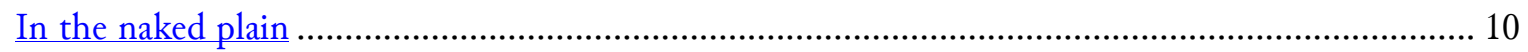

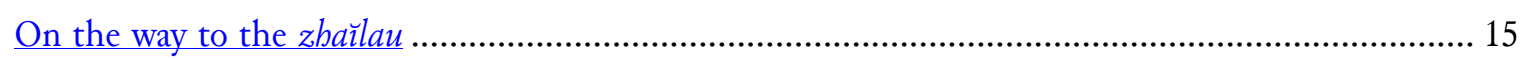

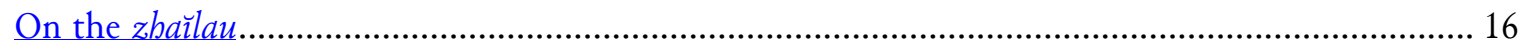

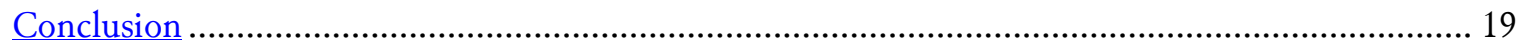

